\title{
African American
}

National Cancer Institute

\section{Source}

National Cancer Institute. African American. NCI Thesaurus. Code C128937.

Denotes a person of African ancestral origins whose family settled in America. 